\title{
MATHEdunesa
}

Jurnal IImiah Pendidikan Matematika Volume 8 No. 2 Tahun 2019

ISSN :2301-9085

\section{ABSTRAKSI REFLEKTIF DALAM MENGONTRUK BANGUN SEGIEMPAT}

\author{
Umi Rif'atul Mardiyah \\ Pendidikan Matematika, MIPA, Universitas Negeri Surabaya, e-mail: umim@mhs.unesa.ac.id \\ Mega Teguh Budiarto \\ Dosen Jurusan Matematika, MIPA, Universitas Negeri Surabaya, e-mail: megatbudirto@gmail.ac.id
}

\begin{abstract}
Abstrak
Penelitian ini tentang profil abstraksi reflektif siswa SMP pada kelompok atas, menengah dan bawah pada materi mengonstruk bangun datar segiempat dengan tujuan penelitiannya yaitu untuk mengetahui proses level-level abstraksi reflekif dalam mengonstruk bangun datar segiempat. Metode penelitian yang digunakan adalah penelitian kualitatif yang bersifat eksploratif dengan data utama berupa kata-kata mengenai bangun datar segiempat dengan subjek penelitian siswa kelas VII SMP RADEN RAHMAT SIDOARJO tahun ajaran 2018-2019 dan terdiri dari 3 siswa (kelompok atas, kelompok menengah, kelompok bawah). Penelitian ditinjau dari 3 aspek yaitu: kemampuan mengenali, merangkai dan mengonstruk bangun datar segiempat. Berdasarkan penelitian yang telah dilaksanakan, disimpulkan bahwa abstraksi reflektif pada kelompok subjek atas, menengah dan bawah dalam mengonstruk hubungan antar segiempat telah melakukan empat level abstraksi reflektif yaitu: (a) pengenalan; (b) representasi; (c) abstraksi struktural; (d) kesadaran struktural; dalam melakukan proses mengenali, merangkai, dan mengonstruk hubungan antar segiempat. Persamaan dari ketiga subjek adalah sama-sama menggunakan atribut panjang sisi dari proses mengenali dan merangkai bangun datar segiempat. Perbedaan dari ketiga subjek adalah hasil akhir proses dari level abstraksi abstraksi reflektif dalam kegiatan mengontruk. Subjek kelompok atas dan kelompok bawah menyendirikan trapesium dari skema hubungan antar segiempat, karena tepat memiliki satu pasang sisi yang sejajar, sedangkan subjek kelompok menengah menyertakan bangun trapesium ke dalam skema hubungan antar segiempat karena memiliki ciri yang sama yaitu sisi yang sejajar.
\end{abstract}

Kata Kunci: Abstraksi Reflektif, Mengonstruk Hubungan Segiempat, Bangun Datar Segiempat.

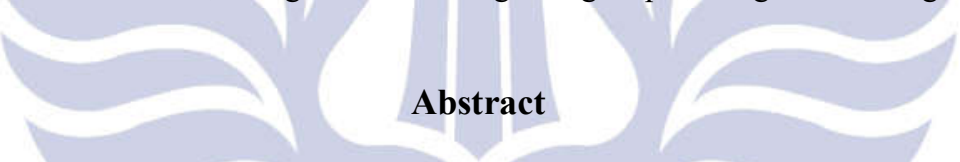

This research about profile of reflective abstraction of the upper, middle and lower subject groups in constructing relation of quadrilateral, with the purpose of research is understanding levels of reflective abstraction process in constructing relation of quadrilateral. The methode of research is an explorative qualitative research with the main data in the form of words on quadrilateral material and the subjects in this study were class VII students of RADEN RAHMAT Junior High School with of the academic year 2018 2019 which consisted of 3 students (upper, middle, and lower group). Research which is reviewed from 3 aspects, namely: the ability to recognize, assemble and construct a rectangular flat building. Based on the research that has been carried out, it is concluded that reflective abstraction of the upper, middle and lower subject groups in constructing inter-quadrilateral relations has carried out four levels of reflective abstraction namely: (a) Recognition; (b) Representation; (c) Structural Abstraction; (d) Structural Awareness; in carrying out the process of recognizing, assembling, and constructing relationships between squares. The equations of the three subjects are both using the side length attribute of the recognition process and in the process of representation to build a rectangular flat. The difference of the three subjects is the final result of the process of the level of reflective abstraction in the contracting activity. The subjects of the upper and lower groups set aside the trapezoid from the scheme of inter-rectangular relations, because it has exactly one pair of parallel sides, while the middle-class subject includes the trapezoidal construct into the quadrilateral relationship scheme because it has the same characteristic that is parallel.

Keywords: Reflective Abstraction, Constructing Quadrilateral Relationships, Quadrilateral.

\section{PENDAHULUAN}

Pemahaman konsep dalam matematika banyak siswa yang mengalami kesulitan dalam memprosesnya dan juga keterbatasan waktu mengajar yang dimiliki guru untuk membangun konsep matematika bagi siswa, sehingga berakibat guru terus melakukan transfer pengetahuan yang telah ada di buku dalam proses kegiatan belajar mengajar. 
Sembiring, dkk (2008) mengatakan, "...the teaching and learning of mathematics in Indonesian schools became mechanistic, with teacher tending to dictate formulas and procedures to their student". Proses kegiatan belajar mengajar matematika di Indonesia menjadi mekanis, jadi guru lebih cenderung untuk mendikte rumus dan prosedur (langkah-langkah) pada siswanya. Guru memberikan rumus secara langsung tanpa menguraikan keterkaitannya dengan konsep yang mendasarinya, sehingga siswa cenderung menyerap prosedur mekanis (langkah melakukan sesuatu) dengan menghafal rumus tersebut dan siswa hanya memiliki pengetahuan prosedural (metode langkah-langkah dalam memecahkan suatu masalah) pada konsep-konsep matematika.

Dalam Pendidikan sekolah dasar sampai ke tingkat perguruan tinggi untuk pembahasan matematik selalu terdapat materi geomeri, karena geometri itu sendiri penting dan lekat dalam kehidupan sehari-hari. Dari masa kini hingga sebelumnya di sekolah dasar untuk pembelajaran geometri selalu berupa pemahaman materi dan pengukuran sudut. Sekarang, sistem geometri dan tilikan (hasil pandangan seseorang) ruang merupakan dua hal yang berkaitan erat dengan sistem bilangan dan cara berfikir numerik, sebagai fondasi untuk pengenalan lebih lanjut tentang matematika. Geometri juga dapat digunakan dalam berbagai bidang terapan (aplikasi).

Clements dan Battista (dalam Budiarto, 2009:4) mengungkapkan bahwa bahwa siswa gagal dalam mempelajari konsep dasar geometri dan menyelesaikan tugas menulis bukti geometri serta kurang memahami unsur-unsur dan dasar-dasar geometri dalam melakukan pendiskripsian untuk hubungan geometris. Rendahnya penguasaan materi geometri di sekolah ditemukan (1) hanya $64 \%$ dari sejumlah siswa yang mengetahui bahwa persegipanjang juga merupakan jajargenjang; (2) 50\% dari sejumlah siswa tidak menyukai masalah pembuktian; (3) siswa lebih baik menyelesaikan permasalahan geometri yang disajikan secara visual dibanding secara verbal. Pengajaran materi geometri dapat melatih siswa untuk berpikir secara nalar dan pengenalan struktur. Hal tersebut karena 5 dasar keterampilan: keterampilan visual untuk mengklasifikasikan bangun geometri menurut atribut yang diamati; kemampuan verbal untuk menunjukkan macammacam bangun geometri menurut namanya atau merumuskan pernyataan generalisasi dan abstraks; keterampilan gambar untuk mengonstruk gambar berdasarkan sifat yang diberikan; keterampilan logika; keterampilan terapan untuk mengonstruk model geometri berdasarkan objek fisiknya. Semua keterampilan tersebut tidak bisa berdiri sendiri tetapi bersifat konprehensif karena geometri itu disusun secara deduktif aksiomatik. Oleh karena itu diharapkan siswa bisa memahami geometri sebagai sebuah struktur. Untuk mencapai geometri secara struktural harus melalui proses abstraksi reflektif.

Berdasarkan uraian tersebut peneliti berencana untuk meneliti profil abstraksi reflektif ssiswa SMP pada kelompok atas, menengah, dan bawah dalam materi mengonstruk bangun datar segiempat, dengan tujuan untuk mendeskripsikan profil abstraksi reflektif siswa SMP yang berkemampuan matematika tinggi, sedang, dan rendah dalam mengonstruk hubungan antar segiempat. Penelitian ini tentang mengonstruk materi konsep bangun datar segiempat menjadi konsep baru dalam bentuk hubungan skema antar bangun dalam prosess abstraksi reflektifnya.

Abstraksi reflektif dari jurnal yang telah ditulis oleh Piaget diungkapkan bahwa hasil akhir dari abstraksi reflektif ialah skema pengetahuan pada setiap tahap perkembangan dan abstraksi reflektif menyarikan skema dari pola aksi yang berkaitan; dan skema itu adalah suatu struktur mental seseorang (Suparno, 2001).

Goodson-Espy (2005) menyatakan dalam aktivitas aktivitas abstraksi reflektif, dapat diketahui bagaimana cara siswa mengonstruk pengetahuan konseptual yaitu dengan car siswa-siswa tersebut memberikan alasanalasan terhadap keputusan yang dibuat. Dalam teori konstruktivis pengetahuan seseorang adalah bentukan/konstruksi orang itu sendiri. Proses pembentukan pengetahuan terjadi jika seseorang mengenbangkan skema hasil abstraksi yang telah dimiliki ketika mendapat masalah. Skema yang dimiliki oleh siswa tersebut dikembangkan untuk membentuk pengetahuan baru. Glasersfeld (dalam Goodson-Espy, 2005:1) yang menjelaskan bahwa, "Reflective abstraction refers to the subject's ability to project on to a new level and reorganize a structurecreated from the subject's own actinities and interpretations". Abstraksi reflektif mengacu pada kemampuan subjek dalam memproyeksikan dan mereorganisasikan struktur yang dimilikinya dari aktivitas dan interpretasi subjek itu sendiri. Sehingga dalam penelitian ini, abstraksi reflektif adalah abstraksi yang diperlukan untuk memperoleh pengetahuan matematis-logis yaitu abstraksi tidak langsung terhadap obbjjek itu sendiri, melalui aktivitas: mengenali, merangkai, dan mengonstruk.

Berikut level-level atau tahap-tahap aktivitas abstraksi reflektif menurut Cifarelli (1988) didefinisikan sebagai berikut: (a) pengenalan (recognition), dalam level ini terdapat aktivitas mengidentifikasi struktur matematika yang telah ada sebelumnya, baik pada aktivitas yang sama maupun aktivitas sebelumnya. Mengidentifikasi berupa mengenali struktur matematika dan ini terjadi ketika seorang siswa menyadari bahwa suatu struktur yang telah ada dan mungkin digunakan sebelumnya melekat pada masalah matematika atau konsep dasar yang dihadapinya kini. Biasanya proses pengenalan terjadi sebagai bagian 
dari aktivitas dengan tujuan lebih dari sekedar aksi pengenalan. Pada proses mengenali, meskipun siswa telah mengenali berbagai hal struktur matematika, tetapi tidak secara otomatis berubah menjadi suatu representasi atau gambaran yang dapat mewakili hal tersebut.; (b) representasi (representation), dalam tahap ini siswa menggunakan diagram di dalam memecahkan suatu masalah untuk membantu refleksi. Refleksi di level ini memerlukan individu untuk mempertunjukkan suatu derajat tingkat fleksibilitas dan kendali tertentu atas aktivitas sebelumnya. Segala aktivitas penyelesaian yang mungkin dilaksanakan, tanpa bisa mengantisipasi hasilnya. Biasanya proses representasi terjadi pada tahap ketika siswa melakukan proses mengonstruk konsep; (c) abstraksi struktural (structural abstraction), dalam proses abstraksi struktural, siswa mampu membuat abstraksi dan representasi aktivitas penyelesaian, mampu untuk merefleksi potensial dari aktivitas sebelumnya, mampu memproyeksikan dan mereorganisasi struktur yang diciptakan dari aktivitas dan interpretasi siswa sendiri kepada suatu situasi baru. Struktur matematika yang ada diproyeksikan dan direorganisasikan, sehingga menambah kedalaman pengetahuan siswa sendiri. Proses mereorganisasi dari konsep matematika merupakan aktivitas mengumpulkan, menyusun, dan mengembangkan unsur-unsur matematis lama menjadi unsur baru. Unsur baru yang dimaksudkan dinyatakan sebagai hasil abstraksi siswa dalam sebuah aktivitas yang sebelumnya tidak dapat mereka peroleh. Dalam pemecahan masalah, subjek mampu memecahkan masalah yang baru dengan menggunakan koordinasi-koordinasi tertentu dari strukturstruktur yang telah dibangun dan direorganisasikan oleh subjek tersebut; tetapi kita tidak tahu apakah subjek sadar atau tidak sadar dalam hal ini.; (d) kesadaran struktur (structural awareness), dalam proses ini siswa akan menunjukkan satu kemampuan untuk mengantisipasi hasil dari aktivitas potensial tanpa harus menyelesaikan semua aktivitas yang dipikirkan. Kesadaran struktural mengacu pada kesadaran metakognisi siswa mengenai aktivitas dan organisasi pada struktur kognitifnya. Siswa mampu memikirkan struktur sedemikian sebagai objek-objek dan mampu membuat keputusan tentang hal tersebut dengan merepresentasikan metode penyelesaian. Pada level abstraksi reflektif yang dikemukakan oleh Cifarelli adalah pada level-level ini merupakan suatu tahapan untuk mendeskripsikan apakah seorang pemecah masalah (problem solver) sadar atau tidak sadar pada konsepkonsep tertentu selama proses pemecahan masalah mereka, dan membantu mengidentifikasi apakah seorang problem solver menggunakan metode penyelesaian sebelumnya atau apakah dia menggunakan metode pemecahan masalah yang baru (Goodson-Espy, 2005).
Materi segiempat yang digunakan adalah tentang konsep pengertian dengan subjek yang diidentifikasi melakukan proses mengonstruk pengertian dari satu atau dua bangun segiempat menjadi suatu penggertian yang baru. Berikut pengertian dari bangun-bangun segiempat: (a) Persegipanjang, yaitu segiempat yang memiliki dua pasang sisi yang berhadapan sama panjang dan satu sudut siku-siku; (b) Pesegi, yaitu segiempat yang semua sisinya sama panjang dan satu sudut siku-siku; (c) Jajargenjang, yaitu segiempat yang memiliki dua pasang sisi berhadapan sejajar; (d) Trapesium, yaitu segiempat yang memiliki tepat sepasang sisi yang sejajar; (e) Layang-layang, yaitu segiempat yang dua pasang sisi berdekatan sama panjang; (f) Belahketupat, yaitu segiempat yang semua sisinya sama panjang.

\section{METODE}

Dalam penelitian ini, ada beberapa tahapan tentang persiapan dan pelaksanaan antara lain: menyusun proposal penelitian, menyusun instrumen penelitian menyusun pedoman wawancara (pedoman wawancara disesuaikan dengan tujuan wawancara yaitu untuk mengetahui abstraksi reflektif siswa dalam mengonstruk hubungan antar segiempat).

Pedoman wawancara sangat diperlukan karena segala sesuatu yang dipikirkan oleh subjek ketika mengerjakan dan menjawab pertanyaan tidak semuanya dituliskan secara tertulis pada lembar jawaban/diungkapkan secara akurat oleh subjek. Instrumen pedoman wawancara dibuat agar memandu dalam mengungkapkan secara mendalam dan detail tentang abstraksi reflektif siswa dalam mengonstruk hubungan antar segiempat. Tujuan dari wawancara berbasis tes ini adalah untuk mencari tahu apa telah dipikirkan oleh subjek yang diteliti dan bagaimana kondisi perilaku mereka ketika dihadapkan pada masalah. Pedoman wawancara yang digunakan adalah yang pedoman wawancara semi-terstruktur. Wawancara semiterstruktur merupakan wawancara secara mendalam dan pelaksanaannya lebih bebas dibandingkan dengan wawancara terstruktur. Wawancara semistruktur membuat subjek akan menemukan permasalahan yang diamati dan mengajak subjek untuk mengemukakan pendapatnya. Subjek dipilih dengan cara diberikan tes kemampuan matematika dengan materi mengenai bangun datar segitiga dan segiempat.

Setelah diberikan tes dan didapatkan hasil nilainya subjek akan dibentuk menjadi 3 kelompok dengan acuan rentang: 1 . Nilai $\geq 80$ dijadikan bagian kelompok atas; 2 . $65 \leq$ nilai $>80$ dijadikan kelompok menengah, dan 3 . Nilai $<65$ dijadikan kelompok bawah. Subjek yang diambil adalah siswa SMP kelas VII yag telah mendapatkan materi bangun datar segiempat di semester genap. Setelah data terkumpul, kemudian data dianalisis dengan menganalisis 
hasil wawancara. Analisis wawancara dilakukan dengan transkrip data (transkrip data yang datanya diambil dari 3 kelompok yaitu pertanyaan, jawaban, dan perilaku responden), reduksi data (reduksi data dilakukan dengan membuat rangkuman inti, proses, dan pertanyaanpertanyaan, kemudian menyusun data dengan melakukan pengelompokan data yang diperoleh sesuai dengan tujuan penelitian), kategorisasi data (kategorisasi difokuskan pada aktivitas pengenalan (Recognition), representasi (Representation), abstraksi struktural (Structurall Abstraction), kesadaran Struktural (Structural Awareness), melalui kegiatan mengenali, merangkai, dan mengonstruk yang dilakukan subjek), penyajian data (penyajian data meliputi pengklasifikasian dan identifikasi data untuk menarik kesimpulan), dan penarikan kesimpulan (data yang sudah dipaparkan dan dibahas secara jelas kemudian ditarik kesimpulan dari data tersebut mengenai abstraksi reflektif siswa).

\section{HASIL DAN PEMBAHASAN}

Abstraksi reflektif subjek 1 dalam melakukan proses mengenali dan merangkai hubungan antar bangun jajargenjang, persegipanjang, belahketupat, persegi, layang-layang, dan trapesium memberikan tindakan recognition, structural abstraction, dan structural awareness dalam melakukan proses mengenali. Sedangkan untuk proses merangkai konsep antar dua bangun segiempat, subjek 1 melakukan tindakan representation. Subjek 1 mampu mengenali ciri dan pengertian dari bangun segiempat yang telah disediakan dan ia juga merangkai hubungan antara dua buah bangun datar segiempat yang memiliki kesamaan dengan diaplikasikan ke dalam jaringan hubungan antar segiempat seperti dalam gambar berikut:

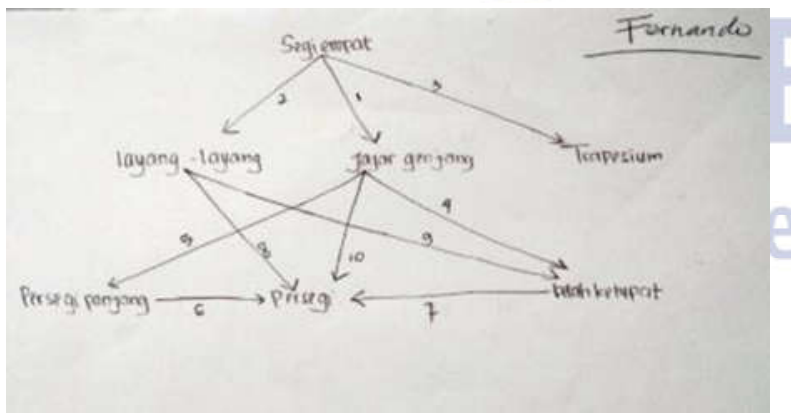

Gambar 1. Jaringan Hubungan antar Segiempat oleh Subjek 1

Gambar 1 tersebut menunjukkan bahwa subjek 1 mampu mengaplikasikan hubungan antar segiempat ke dalam sebuah jaring-jaring. Subjek 1 membuat jaringjaring tersebut dengan menghubungkan nama antar dua bangun dengan tanda panah. Tanda panah menunjukkan bahwa dari bangun yang pertama menuju bangun kedua dihubungkan melalui ciri yang dimiliki kedua bangun. Jika panah mengarah dari bangun pertama ke bangun kedua berarti ciri dari bangun kedua dimiliki oleh bangun pertama, dan nomor pada setiap anak panah menunjukkan aktivitas dari subjek 1 ketika melakukan pertama kali akan diberikan tanda dengan nomor 1 , dst. Proses mengenali bangun segiempat dan hasil mengenali pengertian segiempat oleh subjek 1, bangun trapesium disendirikan karena trapesium hanya tepat memiliki satu pasang sisi yang sejajar dan keempat sisinya memiliki panjang yang tidak sama. Berikut hasil subjek 1 dalam mengonstruk pengertian segiempat: 1 . Trapesium ialah segiempat yang memiliki satu pasang sisi sejajar; 2. Jajargenjang adalah segiempat yang memiliki dua pasang sisi sejajar; 3 . Belahketupat adalah segiempat yang sisinya sama panjang; 4. Layang-layang adalah segiempat yang memiliki dua pasang sisi berdekatan sama panjang; 5. Belahketupat adalah layang-layang yang sisinya sama panjang; 6 . Persegipanjang adalah adalah jajargenjang yang sudutnya siku-siku; 7. Persegi adalah persegipanjang yang sisinya sama panjang; 8. Persegi adalah belahketupat yang bersudut siku-siku; 9. Persegi adalah jajargenjang yang bersudut siku-siku.

Ada 9 hubungan definisi yang dibuat oleh subjek 1, dan 1 diantaranya kurang tepat (nomor 9), karena memiliki dua pasang sisi yang berhadapan sama panjang.

Abstraksi reflektif subjek 2 dalam melakukan proses mengenali dan merangkai hubungan antar bangun jajargenjang, persegipanjang, belahketupat, persegi, layang-layang, dan trapesium memberikan tindakan recognition, structural abstraction, dan structural awareness dalam melakukan proses mengenali. Sedangkan untuk proses merangkai konsep antar dua bangun segiempat, subjek 2 melakukan tindakan representation. Subjek 2 mampu mengenali ciri dan pengertian dari bangun segiempat yang telah disediakan dan ia juga merangkai hubungan antara dua buah bangun datar segiempat yang memiliki kesamaan dengan diaplikasikan ke dalam jaringan hubungan antar segiempat seperti dalam gambar berikut:
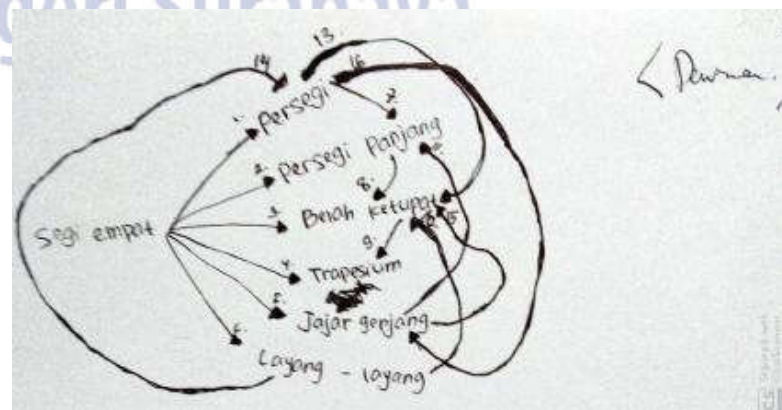

Gambar 2. Jaringan Hubungan antar Segiempat oleh Subjek 2

Gambar 2 tersebut menunjukkan bahwa subjek 2 mampu mengaplikasikan hubungan antar segiempat ke 
dalam sebuah jaring-jaring. Subjek 2 membuat jaringjaring tersebut dengan menghubungkan nama antar dua bangun dengan tanda panah. Tanda panah menunjukkan bahwa dari bangun yang pertama menuju bangun kedua dihubungkan melalui ciri-ciri yang dimiliki oleh kedua bangun. Jika panah mengarah dari bangun pertama ke bangun kedua berarti ciri dari bangun kedua dimiliki oleh bangun pertama, dan nomor pada setiap anak panah menunjukkan aktivitas dari subjek 2 ketika melakukan pertama kali akan diberikan tanda dengan nomor 1 , dst. Subjek 2 menghubungkan semua bangun yang memiliki kesamaan dalam ciri yang dimiliki bangun kedua ke bangun pertama. Dari skema yang dibuat oleh subjek 2, peneliti menanyakan apabila panah yang dibuat oleh subjek 2 dibalik (dari bangun 2 menuju bangun pertama) diperbolehkan atau tidak, subjek menolak karena panah yang menghubungkan kedua bangun memiliki hubungan yang sama dan tidak merubah bentuk. Merubah bentuk yang dimaksud adalah merubah sisi dari sebuah bangun. Misalnya apabila panah dari persegi menuju persegipanjang dibalik maka persegi panjang harus memiliki ciri yang menjadikannya persegi yaitu sisi yang sama panjang. Dalam proses mengenali bangun segiempat, berikut hasil mengenali pengertian segiempat oleh subjek 2 dari pertama sampai terakhir: 1. Jajargenjang adalah segiempat yang mempunyai dua pasang sisi sejajar dan sama panjang dan mempunyai sudut $90^{\circ} ; 2$. Persegipanjang adalah segiempat yang mempunyai dua pasang sisi sejajar dan sama panjang dan mempunyai sudut $90^{\circ} ; 3$. Belahketupat adalah segiempat yang mempunyai 4 sisi yang berhadapan sama panjang dan sejajar; 4. Persegi adalah bangun segiempat yang mempunyai 4 sisi yang sama panjang dan sudutnya $90^{\circ} ; 5$. Trapesium adalah segiempat yang memiliki satu pasang sisi sejajar; 6 . Layang-layang adalah segiempat yang mempunyai dua pasang sisi yang berdekatan sama panjang dan satu pasang sudut berhadapan sama besar; 7. Persegipanjang adalah adalah jajargenjang yang mempunyai sudutnya $90^{\circ} ; 8$. Belahketupat adalah jajargenjang yang sisinya sama panjang; 9. Belahketupat adalah layang-layang yang sisinya sama panjang; 10 . Persegi adalah persegipanjang yang sisinya sama panjang; 11 . Persegi adalah belahketupat yang bersudut $90^{\circ} ; 12$. Persegi adalah jajargenjang yang mempunyai sudut $90^{\circ}$.

Ada 12 pernyataan yang dibuat oleh subjek 2. Dari 12 pernyataan tersebut, 7 pernyataan dinyatakan tepat dan tidak berlebih $(5,7-12), 5$ pernyataan berlebih $(1-4,6)$. Pernyataan dinyatakan berlebih karena memuat satu definisi lagi. Misalnya, persegi adalah bangun segiempat yang mempunyai 4 sisi yang sama panjang dan sudutnya $90^{\circ}$. Agar pernyataan tidak dinyatakan berlebih maka subjek 2 hanya perlu mengurangi kata 4 , sehingga menjadi persegi adalah segiempat yang sisinya sama panjang dan satu sudut siku-siku.

Abstraksi reflektif subjek 3 dalam melakukan proses mengenali dan merangkai hubungan antar bangun jajargenjang, persegipanjang, belahketupat, persegi, layang-layang, dan trapesium memberikan tindakan recognition, structural abstraction, dan structural awareness dalam melakukan proses mengenali. Sedangkan untuk proses merangkai konsep antar dua bangun segiempat, subjek 3 melakukan tindakan representation. Subjek 3 mampu mengenali ciri dan pengertian dari bangun segiempat yang telah disediakan dan ia juga merangkai hubungan antara dua buah bangun datar segiempat yang memiliki kesamaan dengan diaplikasikan ke dalam jaringan hubungan antar segiempat seperti dalam gambar berikut:

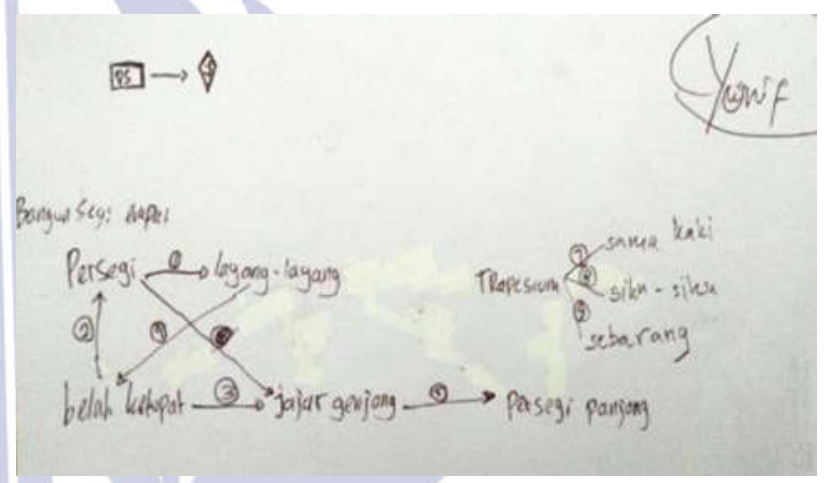

Gambar 3. Jaringan Hubungan antar Segiempat oleh Subjek 3

Gambar 3 tersebut menunjukkan bahwa subjek 3 mampu mengaplikasikan hubungan antar segiempat ke dalam sebuah jaring-jaring. Subjek 3 membuat jaringjaring tersebut dengan menghubungkan nama antar dua bangun dengan tanda panah. Tanda panah menunjukkan bahwa dari bangun yang pertama menuju bangun kedua dihubungkan melalui ciri yang dimiliki kedua bangun. Jika panah mengarah dari bangun pertama ke bangun kedua berarti ciri dari bangun kedua dimiliki oleh bangun pertama, dan nomor pada setiap anak panah menunjukkan aktivitas dari subjek 3 ketika melakukan pertama kali akan diberikan tanda dengan nomor 1 , dst. Proses mengenali bangun segiempat dan hasil mengenali pengertian segiempat oleh subjek 3 , bangun trapesium disendirikan karena trapesium hanya tepat memiliki satu pasang sisi yang sejajar dan keempat sisinya memiliki panjang yang tidak sama. Berikut hasil subjek 3 dalam mengonstruk pengertian segiempat: 1 . Trapesium ialah segiempat yang memiliki satu pasang sisi sejajar; 2. Jajargenjang adalah segiempat yang memiliki dua pasang sisi yang sejajar sama panjangnya; 3 . Belahketupat adalah segiempat yang semua sisinya sama panjang; 4. Layang-layang adalah segiempat yang punya dua pasang sisi berdekatan sama panjang; 5 . Belahketupat adalah layang-layang yang 4 sisinya sama 
panjang; 6. Persegipanjang adalah adalah jajargenjang yang sudutnya siku-siku; 7. Persegi ialah persegipanjang yang 4 sisinya sama panjang; 8. Persegi adalah belahketupat yang bersudut siku-siku.

Ada 8 hubungan definisi yang telah dibuat oleh subjek 3 , dan dari delapan hubungan tersebut ada definisi yang berlebih $(2,3,5,7)$ dan ada yang tepat $(1,4,6,8)$. Subjek 3 juga telah mampu menghubungkan konsep yang lama menjadi konsep baru, meskipun dalam konsep baru tersebut masih mengandung definisi yang berlebih.

Seluruh hasil dari penelitian untuk subjek 1, 2, dan 3 diperoleh dari wawancara yang erbasis tes, dimana seluruh kegiatan subjek direkam dalam bentuk video serta tindakan apapun yang dilakukan oleh subjek diamati dan dicatat. Pembahasan mengenai pengambilan data, analisis, dan pembahasan di depn yang telah diungkapkan oleh peneliti bahwasannya terdapat beberapa kelemahan yang perlu didiskusikan, antara lain: (a). Penggunaan media sedikit kurang aman, karena terdapat beberapa alat dan bahan yang berbahaya seperti cutter dan gunting. (b). Media mudah rusak dan untuk pemakaiannya hanya dapat digunakan sekali pakai. Karena hanya terbuat dari bahan - bahan sederhana dan mudah untuk dicari seperti kertas HVS, batang lidi, dan kertas karton. (c). Media yang digunakan dalam tes sedikit, sehingga subjek lebih mudah dalam mengelompokkan bangun datar. (d). Kelemahan pada pemahaman subjek pada wawancara berbasis tes dan reorganisasi konsep, yang belum bisa diberikan dan menyelesaikan tes dengan model lain, contoh menghitung dan membandingkan dua bangun datar segiempat, serta mencari ciri-ciri yang lain misalnya sumbu simetri yang dimiliki bangun datar segiempat, simetri lipat, dll. (e). Subjek yang dipilih per tiap kelompok hanya satu subjek dan dari sekolah yang sama, sehingga memungkinkan terjadinya kerjasama antar subjek dari kelompok atas, menengah, dan bawah ketika ada jeda pergantian.

\section{PENUTUP}

\section{Simpulan}

Peneliti mengambil kesimpulan dari analisis dan pembahasan yang ditulis di depan bahwa:

1. Atribut dalam mengenali bangun datar segiempat (jajargenjang, persegipanjang, persegi, belahketupat, layang-layang, dan trapesium) adalah panjang dan lebar sisi, banyak sudut, bentuk, besar sudut, macammacam sudut. Kelompok atas dan menengah mengemukakan atribut nonrutin (panjang sudut dan bentuk sisi), kelompok bawah tidak mengemukakan atribut nonrutin. Subjek mengelompokkan berdasarkan warna, jumlah sisi, sudut dan panjang sisi.

2. Abstraksi reflektif subjek kelompok atas, menengah dan bawah dalam mengonstruk bangun datar segiempat telah melakukan proses level-level abstraksi reflektif Cifarelli yaitu, recognition (kegiatan mengenali), representation (kegiatan merangkai), structural abstraction (kegiatan mengenali), dan structural awareness (kegiatan mengenali).

3. Persamaan ketiga subjek adalah menggunakan atribut panjang sisi dari proses mengenali (dalam proses recognition, structural abstraction, structural awareness) dan merangkai (dalam proses representation) bangun datar segiempat dan perbedaannya adalah hasil akhir proses dari level abstraksi reflektif dalam kegiatan mengontruk.

\section{Saran}

Berdasarkan pembahasan di depan, dapat disimpulkan saran yaitu:

1. Untuk para guru pengajar matematika, diharapkan lebih menerapkan keraguan agar siswa dalam memahami konsep matematika bisa lebih mendalam.

2. Bagi pihak sekolah, diharapkan juga menekankan sikap keraguan subjek lebih banyak ketika subjek ingin melakukan reorganisasi konsep sehingga subjek lebih mampu dalam membentuk konsep matematika yang tepat dan sebelum dilakukan tes subjek telah menerima materi bangun datar segiempat yang matang.

3. Bagi pihak terkait dan peneliti selanjutnya, sebaiknya menyediakan/menggunakan media yang aman agar tidak melukai subjek peelitian.

4. Menggunakan bahan media yang tidak mudah rusak seperti plastik berbahan mika yang tidak mudah terkena air dan memperbanyak jumlah pembuatan media yang dianggap kurang. Misal dengan menambah model bangun datar yang disediakan untuk tes pertama (mengenali dan mengelompokkan antar bangun datar).

5. Membuat kelompok yang terdiri dari 6 subjek (2 subjek kelompok atas, 2 subjek kelompok menengah, 2 subjek kelompok bawah) dan dari keenam subjek tersebut lebih baik jika diambil dari sekolahan yang berbeda agar tidak terjadi kerjasama antar subjek.

\section{DAFTAR PUSTAKA}

Budiarto, M. T. (2009). Abstraksi Dalam Geometri: Pidato Pengukuhan. Surabaya: Departemen Pendidikan Nasional Universitas Negeri Surabaya

Cifarelli, V. V. (1988). The role of abstraction as a learning process in mathematical problem solving. Doctoral dissertation, Purdue University, Indiana. USA. 
Goodson-Espy, T. (2005). Why Reflective Abstraction Remains Relevans in Mathematics Education Research Inc.

Sembiring R.K., Sutarto H., \& Maarten D., (2008). Reforming mathematics learning in Indonesian classroom through RME. ZDM: The International Journal on Mathematics Education, 40(6), 927-939.
Suparno, Paul. (2001). Teori Perkembangan Kognitif Jean Piaget. Yogyakarta: Kanisius

Wiryanto. (2014). Level-Level Abstraksi Pemecahan Masalah Matematika. Jurnal Pendidikan Teknik Elektro, Vol. 03, No. 03, 569-578.

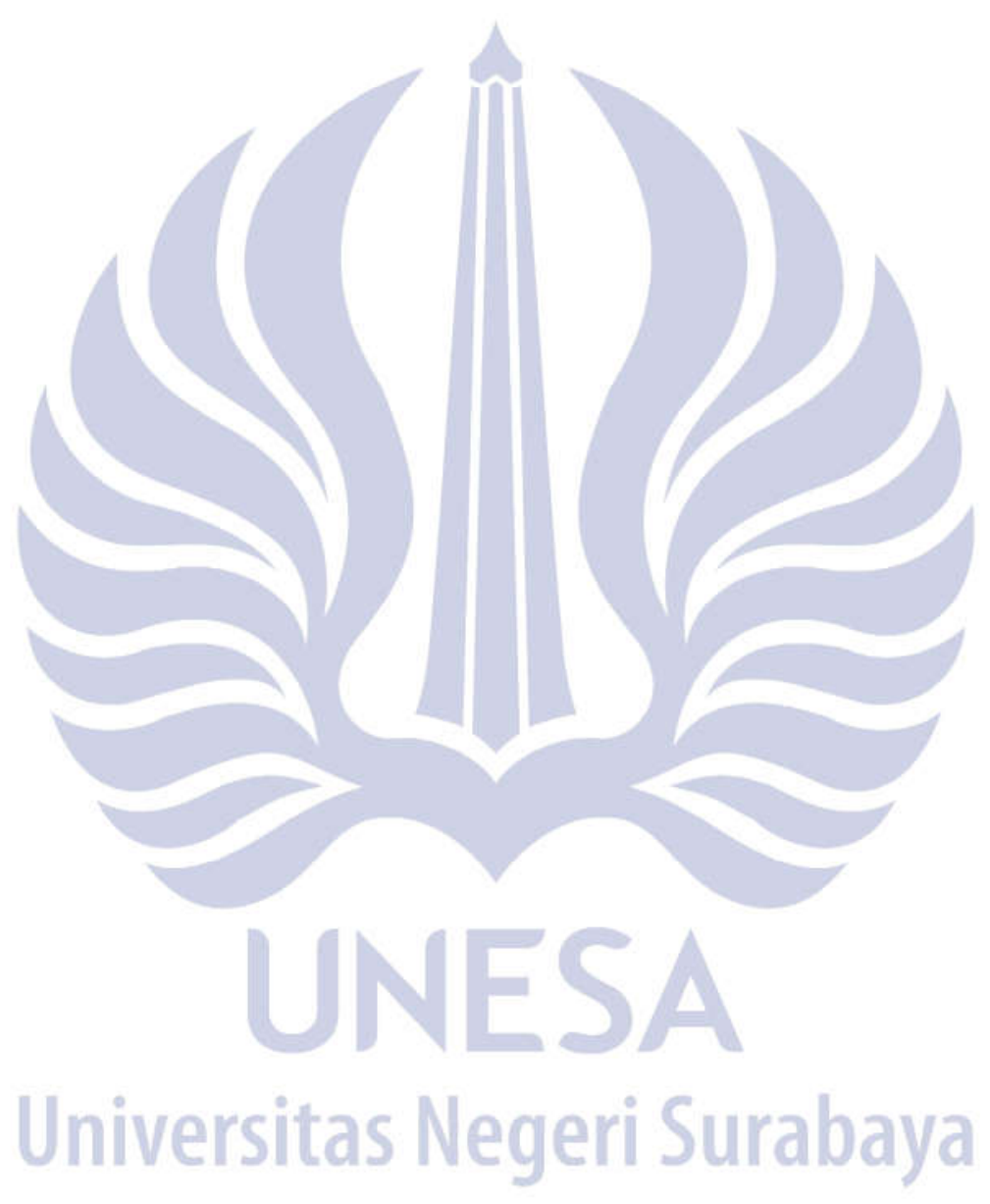

